\title{
地上据置型レーザスキャナを用いた地形計測結果からの樹木の自動除去
}

\section{Automatic tree data removal method for topography measurement result using terrestrial laser scanner}

\author{
横山 大*・近津 博文* \\ Hiroshi YOKOYAMA and Hirofumi CHIKATSU
}

\begin{abstract}
Recently, laser scanning has been receiving greater attention as a useful tool for real-time 3D data acquisition, and various applications such as city modelling, DTM generation and 3D modelling of cultural heritage sites have been proposed. And, former digital data processing was demanded in the past digital archive techniques for cultural heritage sites.

However, robust filtering method for distinguishing on- and off-terrain points by terrestrial laser scanner still have many issues. In the past investigation, former digital data processing using air-bone laser scanner were reported. Though, efficient tree removal methods from terrain points for the cultural heritage are not considered.

In this paper, authors describe a new robust filtering method for cultural heritage using terrestrial laser scanner with "the echo digital processing technology" as latest data processing techniques of terrestrial laser scanner.
\end{abstract}

\section{1 . はじめに}

近年のデジタル技術や画像処理技術の飛躍的な発展 を背景に，文化資産の修復や記録，バーチャルリアリ ティの構築等の観点から遺構や文化財，美術品の記録 手法としてデジタルアーカイブ化が注目されており, デジタルアーカイブ化を行うために海外での大型調查 プロジェクトも組まれている(池内，大石，2010)。こ のデジタルアーカイブ化に抒いて, 以前のデジタル アーカイブ化では文化財の形状に関するデジタルデー 夕化だけが求められていたが, 最近ではインフラの整 備や処理システムの高性能化に伴い, 従来の $3 \mathrm{D} C \mathrm{CG}$ を利用した文化財の記録だけでなく，膨大なデー夕を 用いた AR (Augmented Reality，拡張型現実)や GIS など様々な分野での活用が検討されている（大野他， 2009)。このデジタルアーカイブ化を推進するにあたっ ては，GIS との連携などが模索されるに伴って所在地 や出土場所，調查結果などのデー夕の付加が求められ

*東京電機大学理工学部創造工学系

Department of Civil Eng., Tokyo Denki Univ.

「写真測量とリモートセンシング」VOL. 54，NO. 5， 2015
る様になり, さらにはデータサイズも日々増加する傾 向にあることから, 幾何デー夕の取得およびその後の 三次元モデリングでの作業について, 如何に労力を減 らすかという観点からの作業の自動化が検討課題と なっている。特に遺跡を対象とした三次元計測を行っ た場合, 取得したデー夕に対する樹木等の不要なデー 夕の除去が必要となり, 計測デー夕の自動分類とその 結果に基づいた地形以外のデータの自動除去という作 業の自動化が望まれる。

レーザスキャナ計測によって取得される点群データ を対象とした計測データの自動分類においては, 画像 処理で主に使用され, 注目点と近傍の点の比較を行う モルフォロジー処理や高さ情報を使った手法が近年で は検討されている（Bordu, Lague，2012，Pirotti 他， 2013）が，樹木と凹凸の激しい地形が複雑に入り組ん だ場所では検討範囲の設定やしきい值の設定が難し く, 分類には経験や教師デー夕の処理結果に基づいた しきい值の設定作業が必要となる。さらに, データの 分類を行った際には誤分類が発生するが, その際の データの補間または誤分類した部分のデータの復活方 法において, 検討を行う必要がある。その他の手法と して, 2 次元画像では pixel という概念を 3 次元に拡 張し， 3 次元空間での正規格子単位として表す voxel 
という概念を用いた方法も提案されている（Lim 他， 2009）。しかし，この方法は voxel の活用によってモデ 儿作成時に使用する点データの数が抑えられるという メリットがあるものの, voxelの設定サイズによって 能力が異なることになる，比較的平坦な地形やビルな どのモデルでは大きなサイズでの voxel が設定でき るが複雑な凹凸の地形では voxel のサイズを小さく する必要があるためにデー夕処理が大きくなり，適用 効果が薄れるため, 別種の方法での検討が望まれてい る。

一方, 遺構の計測が含まれる最近の地形計測の分野 では，地上据置型レーザスキャナが詳細な地形計測を 可能とする手法として注目されているが，計測結果で ある三次元点群デー夕から地形モデルを作成するため には地表面を覆う樹木等を取り除き, 地表面が効率的 に検出されなければならない。過去の研究においては, 航空機レーザ計測を用いた樹木を含めた計測と森林の 解析に関する研究が数多く行われており, 地上据置型 レーザスキャナを用いた方法でも検討はなされている が，樹高の計測や植生分類や外形の再現などが行われ ており（押尾他，2013， Schilling 他，2012），文化財の 記録に求められる地表面からの樹木の除去までは至っ ていない。

このような地表面からの樹木の除去が求められる状 況において，地上レーザ測量から得られる三次元点群 デー夕から地表面を効率的に検出するため, 注目点を 含む微小領域に対する面の平坦度に着目し, 平坦度に より微小領域を平坦部分（地表やビル壁面等）と非平 坦部分（樹木や下草等）とに分類する方法が発表され ている(横山，近津，2004）。この平坦性評価を用いた 手法では，平坦性の高い（凹凸の少ない）地形と平坦 性の低い（凹凸の激しい）樹木の分類は容易となって いるが，凹凸の変化が激しい地形と大木，手すりや看 板の下部である杭状のものなどが混在している場所か ら地形のみを抽出することは実現されていない。

本研究では, この平坦性評価を用いた方法に加え, 最近の地上据置型レーザスキャナで用いられている デー夕処理技術であり, 反射エコーに含まれている直 近のターゲットを示す First Targetや最奥のター ゲットを示す Last Target 等の異なる信号の種類を 処理し，抽出する「エコーデジタル処理技術」を用い ながら，平坦性評価を用いた手法とエッジ特徽量を用 いた方法の組み合わせや主成分分析を用いた方法と
いった複数の手法による遺跡の計測結果から樹木等の 地形以外のデー夕を自動で除去する能力について比較 を行い，樹木の除去プロセスを追加することで，地形 計測結果から樹木を自動で除去する手法の検討を行っ た。さらに，樹木の自動除去を行った後の地形に対し て周辺の状況から推測される理想的な点の位置関係を 用いることで，誤除去した地形デー夕の復活を行う方 法についても検討を行った。

\section{2. 地形計測データからの樹木の自動除去}

遺跡を対象としたデジタルアーカイブデータの作成 に関しては, 経年変化による劣化や地震による地形崩 壊, 土地開発に伴う破呆前の調査などにおいて現在の 状態を詳細に記録する必要性があり, 詳細な地形情報 や平坦部分と非平坦部分の境界 (稜線, 溝の端部) で あるブレイクラインを記録している。文化財のブレイ クライン (稜線) の記録については, 従来は手計測や トータルステーション, 写真測量, レーザスキャナな どを用いた方法が採用されているが, 膨大な労力と時 間をかけて行われているため, 作業の自動化が求めら れている(山内他，2008，西村他，2012）。

最近のレーザスキャナでは，照射するレーザの反射 データを瞬時に分析する「エコーデジタル処理技術」 も活用されるようになってきている。よって, 合理化 が求められている文化財や地形計測などの分野で地上 据置型レーザスキャナを用いた計測の後, 計測した地 形情報から遺跡の調查結果として不要なデー夕となる 樹木を効率的な方法で自動除去を行う場合, 図 1 に示 す作業フローとなる。

遺構の計測のうち, 横穴墓群遺跡を対象としたデジ タルアーカイブでは記録対象である斜面の中腹などに 多数の樹木が存在するため, 地形から樹木を自動で除 去する必要がある。樹木に関するデー夕を除去するに あたって地形変化を観察する場合, 遺跡部分の地形は なだらかな連続した変化となっているのに対し，樹木 部分は急激な変化が連続している。そのため, 注目点 とその周辺の形状を考慮した平坦性評価を行うことで ある程度の地形と樹木の自動分類が可能となる。

さらに，近年の地上据置型レーザスキャナでは，照 射するレーザの反射データに基づき, 反射データの状 態を瞬時に分析する「エコーデジタル処理技術」も活 用されるようになってきている。従来，この技術は航 


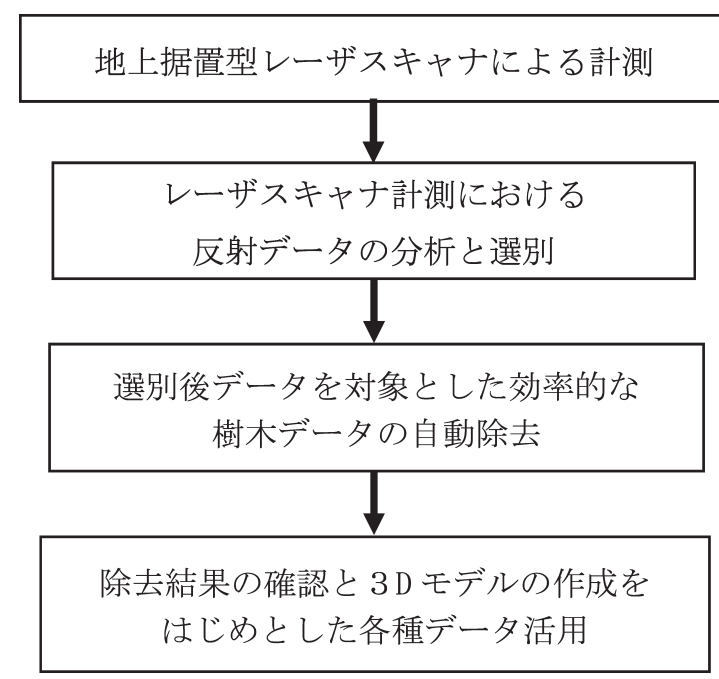

図 1 地上据置型レーザスキャナを用いた樹木の自動除去 にかかわる作業フロー

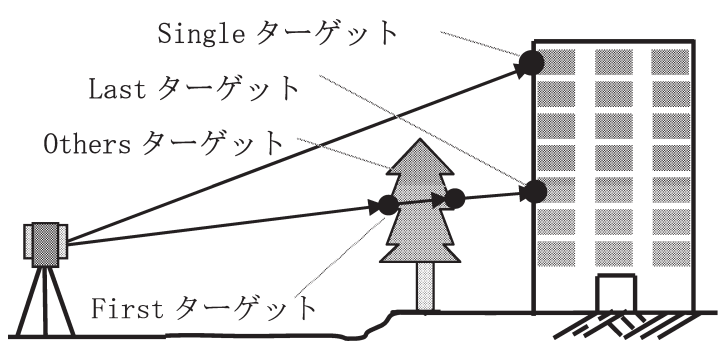

図 2 反射信号分類イメージ

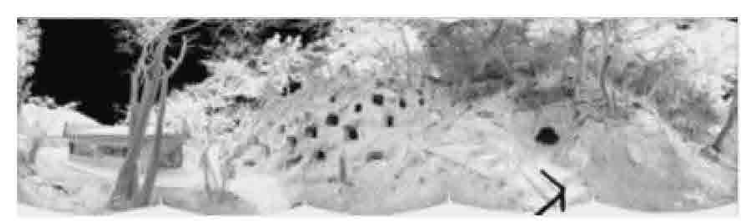

(a) 計測対象（色付点群デー夕）

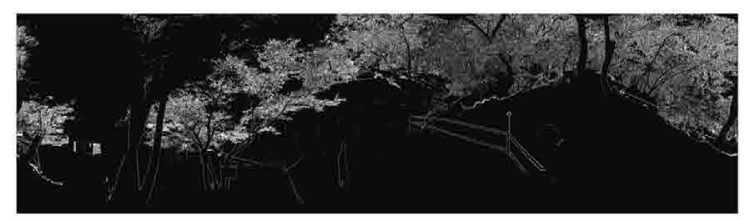

(c) Last ターゲット

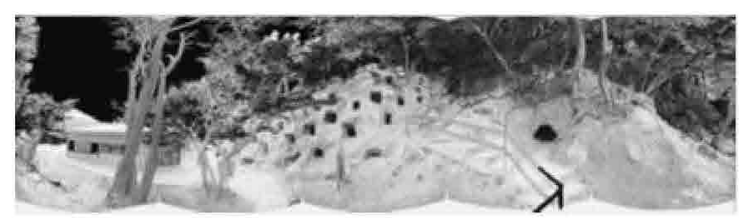

(e) Single ターゲット
空機搭載レーザスキャナで用いられていたデー夕処理 技術だが，地上据置型レーザスキャナの場合は対象物 に向けたレーザの反射信号を図 2 に示すように First ターゲット, Lastターゲット, Othersターゲット, Single ターゲットに分類することができる。すなわ ち，樹木の葉が重なる部分のようにレーザが葉群の空 隙を通り抜けるような場合には, 反射信号が複数検出 されることとなる。この複数の検出された信号につい ては, 最初の反射として検出された位置を First 夕一 ゲット，最後の反射として検出された位置をLast ターゲット，その中間で検出された反射信号を Others ターゲット，壁面を計測した時のような複数の反射信 号が検出されないデー夕は Single ターゲットとして 定義されている。そ己で本研究では，平坦性評価手法 に加え，反射データも活用した樹木の自動除去を行う ことにした。

図 3 (a)は, 本研究の計測対象である埼玉県の吉見百 穴（古墳時代後期の横穴墓群の遺跡）を表 1 に示す地 上据置型レーザスキャナを用い，角度振角を0.04 deg とした計測で取得した色付点群データであり，計測範 囲は水平方向で約 $190 \mathrm{~m}$ の広さとなる。また, 計測結果 には地形と樹木以外に, 観光地であるために建物, 歩 道の階段や手すり，立看板といったものが計測結果に 含まれている。四 3 (b)〜 (e)は樹木を含んだ遺跡(地形)

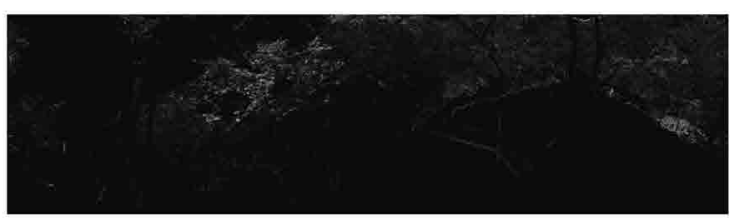

(b) First ターゲット

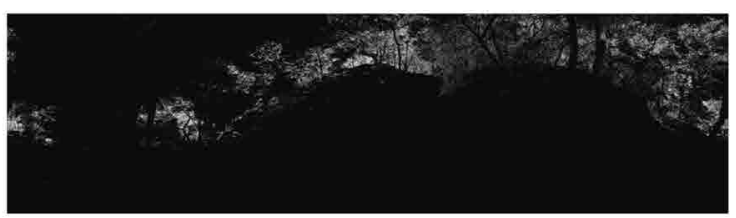

(d) Others ターゲット

図 3 反射信号別計測結果 
表 1 レーザスキャナ諸元

\begin{tabular}{|c|c|}
\hline 機種名 & $\mathrm{VZ}-400$ \\
\hline メーカ & リーグル \\
\hline 測定範囲 & 〜350m（高速モード） \\
\hline スキャニング角 & $\begin{array}{l}\text { 垂直： } \pm 50^{\circ}\left(100^{\circ}\right) \\
\text { 水平： } \pm 180^{\circ}\left(360^{\circ}\right)\end{array}$ \\
\hline スキャニング速度 & 122,000ポイント/秒 \\
\hline 測定精度 & 標準 $： \pm 5$ mm \\
\hline 本体サイズ・重量 & $\begin{array}{l}308 \mathrm{~mm} \text { (長さ) } \times \phi 180 \mathrm{~mm} \text { (直径), } \\
9.6 \mathrm{~kg}\end{array}$ \\
\hline
\end{tabular}

を計測した際の反射信号別の計測結果であり，樹木の 葉などの部分は First ターゲットとして検出されてい ることが確認される。また, Single ターゲットにおい て樹木の葉の部分と推定されるデータが存在するが, これは葉の後ろの部分にデータが存在しない, 葉の厚 みで後方にレーザが通らないなどの理由により, Single データとして検出されたデー夕と推定される。そ のため，樹木などの自動除去を行う場合には一部の樹 木の葉のデー夕を考慮する必要があるが, Single 夕ー ゲットのみを対象とすることで確実に葉の部分と断定 される部分を除外した検討を行うことができる。

なお，図 3 の計測データでは, Singleターゲットは 全体の約77\%のデー夕量, First ターゲットは約11\%, Last ターゲットは約10\%, Others ターゲットは約 $2 \%$ という内訳となっている。

\section{3. 点群データからの樹木除去方法}

\section{1 平坦性評価手法}

地上据置型レーザスキャナを用いた地上レーザ測量 では, 機器を中心として放射方向にレーザ光を掃射し ながら三次元点群デー夕を取得する。それに伴い,レー ザスキャナから計測点までの距離によって点密度が変 化するため, 計測結果の一つである距離画像上で一定 サイズのマスクを設定しても各マスクに対する辺の実 長が同じ大きさになるとは限らない。本研究では, 図 4 に示すように三次元点群デー夕に基づいて作成され る距離画像上に, 注目点を中心とした $3 \times 3$ ドットを 最小サイズとする矩形マスクを最初に設定し，各点に 対応付けられている三次元データから矩形マスクの 1 辺の実長を求め, その長さが縦横共に過去の研究（横 山, 2004)によって活用されている所定の長さ $(0.3 \mathrm{~m} \times$

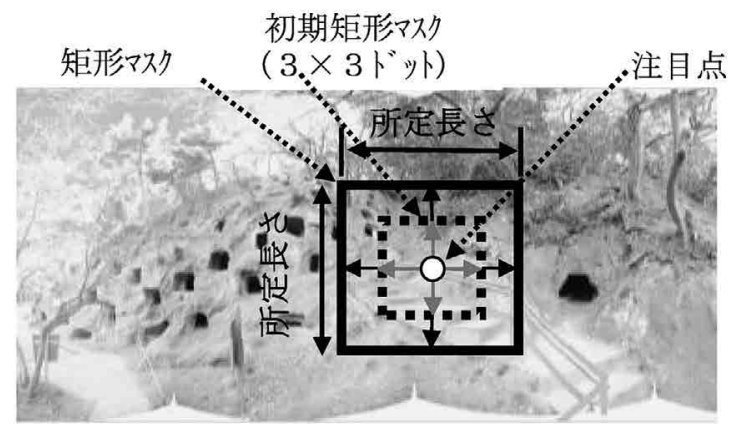

図 4 可変矩形マスクの適用イメージ

$0.3 \mathrm{~m})$ になるまで距離画像上のマスクサイズを拡大す る。

次に, マスクの 4 隅と外周中央の計 8 点およびマス ク中央に位置する注目点の合計 9 点を用いて 8 つの三 角形を作成した後, 三角形頂点の三次元デー夕を用い て各三角形の法線ベクトルを算出する。算出した三角 形の法線ベクトルは, 三角形のベクトル成分の平均を 求めることで合成法線ベクトルを算出し, 算出した合 成法線ベクトルを矩形マスク (参照領域) に対する法 線ベクトルとする。ところで, 法線ベクトルの方向は 注目点が地上であるか, 壁面であるか, 等によって様及 な方向を取ることになる。そこで，マスク内に含まれ るすべての三次元点群データについてマスクに対する 法線ベクトルの向きが $Z$ 軸と平行になるように注目 点を中心として座標変換を行い, 面の向きが XY 平面 にほぼ平行な状態とした後に, マスク内に含まれる全 点群データの Z 值から面の凹凸に対する標準偏差を 求める。このように本研究では画像上に予婝められ た大きさの矩形マスク (参照領域) を設定し, その向 きを法線べクトルによって揃えることで，参照領域に 対する平坦度を算出する。本研究では座標変換後の面 の凹凸に対する標準偏差を注目点での平坦性を表す指 標（単位：m）として定義する。

図 3 (a)に示した遺構計測結果に対し, 計測結果に基 づいて作成された距離画像と受光強度画像, 平坦度画 像を図 5 に示す。距離画像は, 地上据置型レーザスキャ ナから遠距離になるほど白色で表現されており, 受光 強度画像はレーザの反射度合いで色を表現している。 また, 図 5 (c)の平坦度画像は, 計測結果から算出した 平坦度を用いることで作成した平坦度画像であり, 平 坦度が大きいほど白色で表示しているが，この図から 樹木の葉部分などの遺跡のデー夕を残すためには不要 


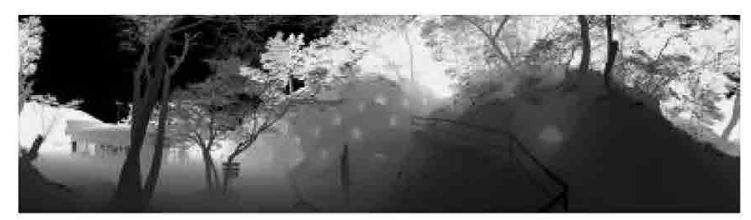

(a) 距離画像

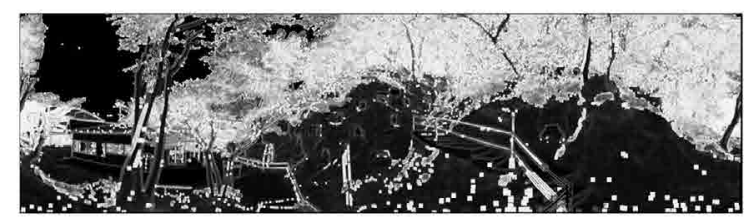

(c) 平坦度画像

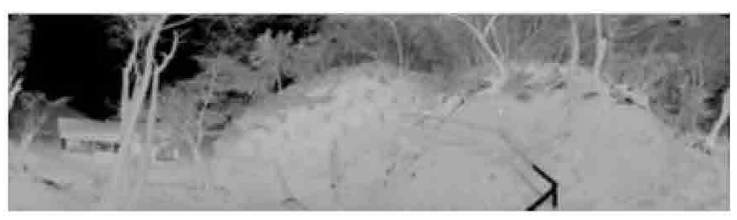

(b) 受光強度画像

図 5 遺跡を対象とした計測結果

なデータが白色に近い色として表現されていることが 確認される。

遺跡を対象としたレーザスキャ十計測結果からの樹 木の自動除去において,図 3 に示した計測結果のうち, Single, Last ターゲットにおいてデータが確認される 点のみを注目点として平坦性評価手法を適用し, 樹木 と判断されたデー夕を除去した結果を図 6 に示す。な お, 本研究では地形と樹木を分けるとされる平坦度を 植込みと道路脇護岸の中間となる $0.030 \mathrm{~m}$ を設定し, それ以上となる点を樹木として除去することとした。 また,レーザが透過しない最終到達点である Single, Lastデータに対してレーザが透過する First, Others デー夕は全体の $13 \%$ 程度のデー夕量となる。平坦性評 価手法を適用するにあたり，大きな影響は与えないが， すべての計測点に対して平坦度の算出を行う場合に比 べて多少なりとも計算に要する負荷を減らすことが可 能となるため, 遺跡計測結果からの効率的な樹木の自 動除去を行うことが可能となる。しかし, 図 6 の除去 結果では一部に樹木のデータが部分的に残っており, 追加プロセスによる樹木の除去が必要となることが確
認された。

3.2 エッジ特徴量を用いた樹木の自動除去方法の追加 図 6 では平坦性評価を用いた手法によって多くの枝 葉の部分を効率的に除去できることが確認されたが, 太い幹のように局所的にみると平面と判断されると思 しき場所が除去しきれていないため，本研究では平坦 性評価と反射データの組み合わせに加え, 新たな樹木 除去プロセスを検討した。

新たな樹木除去プロセスの検討にあたり，図 6 の結 果において削除すべきデー夕を確認した結果，樹木の 幹や枝などの円筒形の形状であることが判明した。一 方，残すべきデータは地形であり，凹凸の連続した形 状のため, 図 6 で確認されているデー夕から円筒形に 近い形状のデータを削除することにした。円筒形の形 状を認識するにあたっては, 注目点を中心とした局所 的な面の向きを解析し, 円筒形をなすような変化を示 す部分を樹木として認識する方法が考えられる。

一方，画像処理においては色の変化を分析すること でエッジ抽出が行われるが，このエッジ特徵量をべク

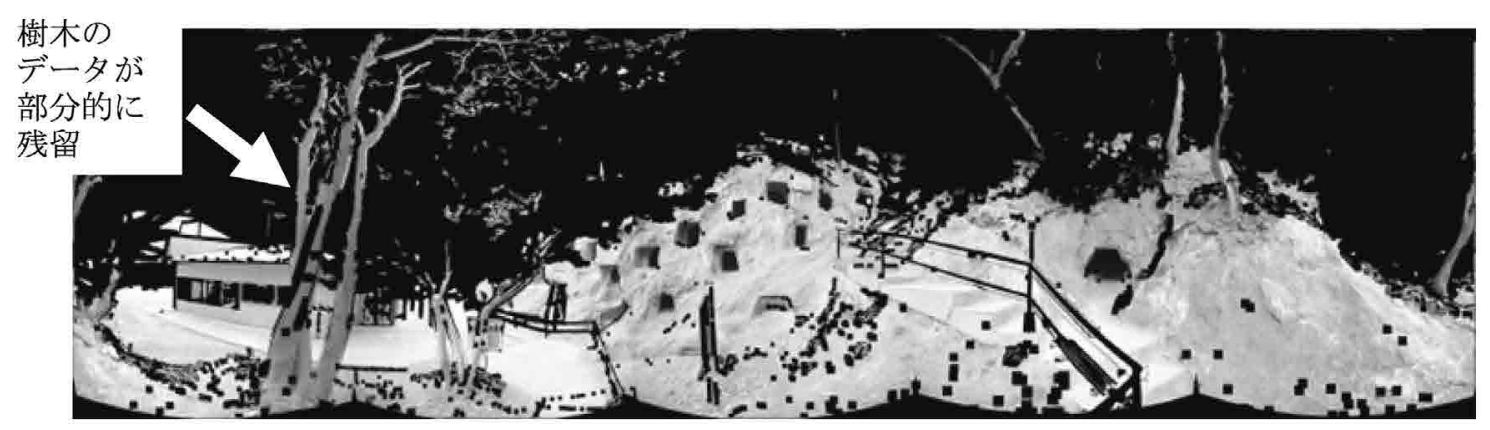

図 6 平坦性評価による自動除去結果 
トルで表示する方法がある(杉山，阿部，1997)。この 方法においては，(1)式にしたがって画像上の注目点に おけるエッジの方向性を算出し，(1)式中にあるXY 方 向成分は(2)式によって算出する。

$\vec{h}(x, y)=\left(h_{x}(x, y), h_{y}(x, y)\right)$

ここに,

$\vec{h}(x, y)$ : 注目点におけるエッジのベクトル, $h_{x}(x, y)$, $h_{y}(x, y)$ : 注目点におけるエッジベクトルの $x, y$ 成分 $h_{x}(x, y)$

$=\int_{-\pi}^{\pi} \int_{0}^{\infty} f(x+r \cos \theta, y+r \sin \theta) w(r) \cos \theta d r d \theta$

$h_{y}(x, y)$

$=\int_{-\pi}^{\pi} \int_{0}^{\infty} f(x+r \cos \theta, y+r \sin \theta) w(r) \sin \theta d r d \theta$

ここに

$w(r)$ : 重み関数, $r$ : 注目点からの画像上の距離

さらに，エッジベクトルの方向成分を用いてエッジ の方向 $\theta(x, y)$ を算出する式を(3)式として定めてい る。

$\theta(x, y)=\arctan \left(h_{y}(x, y) / h_{x}(x, y)\right)$

本方法では画像の輝度值を使用するが，本研究で対 象としているデー夕は三次元の位置情報をもつ点群 デー夕であるため，この方法をそのまま適用すること はできない。しかし，図5(a)に示すように点群データ から距離画像などを作成しており，距離画像上の各点 には三次元位置情報だけでなく, 法線べクトルなどの 各種データを対応付けることが可能となっている。そ のため, 距離画像上の点と各点に対応付けられている 各種デー夕を用いることで，本方法を活用することが 可能となる。
本研究では，樹木を除去するために円筒形に近い形 状のデー夕を除去することにしているが，特に法線べ クトルの変化に着目することにした。すなわち, 円筒 形の法線べクトルの変化に着目した場合，枝が伸びる 軸方向に対して水平面となる方向になる法線べクトル は大きく変化する。そのため, 最初に距離画像上での $\mathrm{X}$ 方向, $\mathrm{Y}$ 方向の各軸の法線ベクトルの変化を検討 し, 距離画像上での変化の方向性を確認する。この過 程により, 距離画像上の上下方向, 左右方向のいずれ に樹木が伸びているかが判別できる。つぎに樹木の伸 びに対して水平面となる方向，すなわち距離画像上で 確認された樹木の伸びている方向が上下方向であれば 左右方向に位置する隣接点について法線ベクトルの変 化を検討し，樹木の伸びている方向（上下方向）を示 す軸周りの法線べクトルの変化が他の二軸に比べて大 きい注目点については樹木であると判断し, 計測結果 から除去することにした。

遺跡を対象としたレーザスキャナ計測結果からの樹 木の自動除去において, 図 3 に示した反射信号別計測 結果のうち, Single ターゲットについて平坦性評価手 法を適用した結果を図 7 に示す。Single データに対し て平坦性評価手法を適用することで, すべての計測点 に対して平坦度の算出を行う必要性がないために, 遺 跡計測結果からの効率的な樹木の自動除去を行うこと が可能となる。しかし，太い幹を持つ樹木の根元部分 などのデータについては除去しきれていない状況にあ る。

しかし，樹木は細長い形状であるために面の向きを 正確に判断することが難しく，地形の稜線のような部 分も形状によっては樹木と判断される可能性が高いた め，追加の樹木除去方法を追加するなどのように本方 法をこれ以上深く検討することはできないと判断し

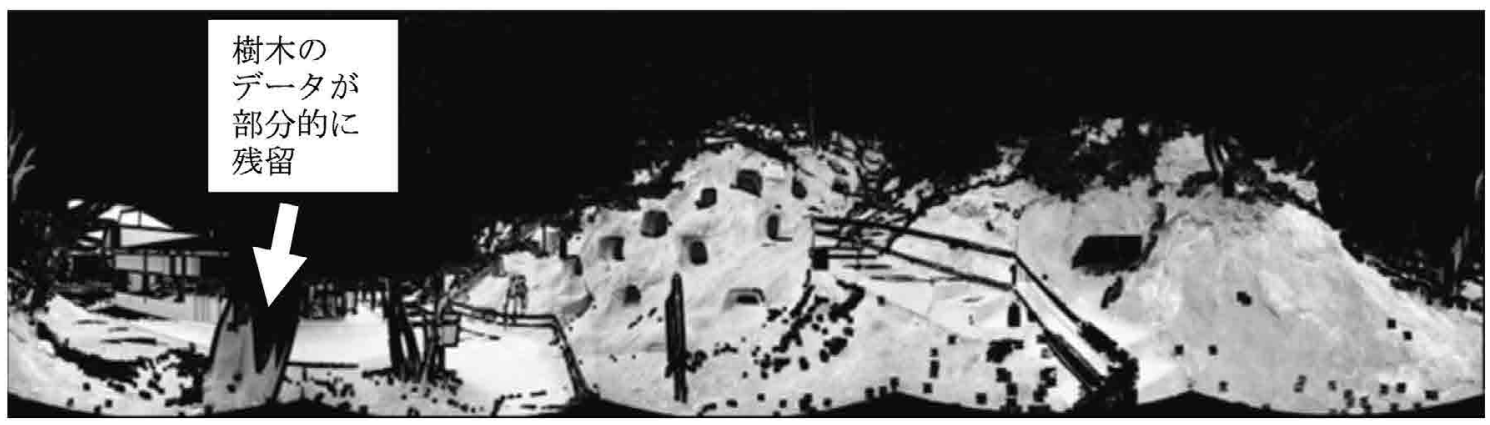

図 7 エッジ特徵量をべクトルで表示する方法による樹木除去結果 
対応する固有べクトルとなる。

\section{3 主成分分析を用いた樹木の自動除去方法の検討}

樹木の除去方法を新規に検討するにあたって樹木の 形状を再確認すると，分岐はあるが基本的には筒状の 形状の集合体であり，注目点を中心として隣接する点 との位置関係を分析することで樹木の検出が可能にな ると推測される。

一方, 情報学の分野では統計的な手法を用いてデー 夕の傾向分析を行う主成分分析という方法がある。主 成分分析は，複数の結果変数からなる変量デー夕を統 計的に扱う多変量解析に含まれる手法であり, 構成さ れるデータから相関係数行列 $\mathrm{R}$ を算出し, 第一固有值 （最大固有值）근対応する固有ベクトルから第一主 成分 $z_{1}$ を算出した後, さらに構成するすべての多次元 デー夕について主成分を算出する。さらに，それぞれ の主成分の寄与率, 累積寄与率, 因子負荷量, 主成分 得点を算出し, 最後に算出した各種デー夕に基づいて, デー夕の傾向を分析するものである（上田，2003，永 田，棟近，2001）。

本研究で取り扱うデー夕は三次元データであり, 変 数が 3 となる場合の主成分分析プロセスが必要とな り，最初にデータの標準化を(4)式によって行う。

$u_{1}=\frac{x_{1}-\overline{x_{1}}}{s_{1}}, \quad u_{2}=\frac{x_{2}-\overline{x_{2}}}{s_{2}}, \quad u_{3}=\frac{x_{3}-\overline{x_{3}}}{s_{3}}$

ここに,

$u=$ 標準化デー夕, $x=$ 変数, $\bar{x}=$ 変数の平均, $s=$ 変数の標準偏差

さらに，第一主成分 $z_{1}$ を(5)式によって算出する。

$z_{1}=a_{1} u_{1}+a_{2} u_{2}+a_{3} u_{3}$

ここに

$a=$ 固有ベクトル

なお，主成分の算出にあたっては固有ベクトルにな んらかの制限を設けない場合はいくらでも大きい值と なるため，次式の条件を設定する。

$a_{1}^{2}+a_{2}^{2}+a_{3}^{2}=1$

上記の(5)式，(6)式を使用して，第一主成分 $z_{1}$ であれ ば分散 $V_{z 1}$ が最大となる $\left[a_{1}, a_{2}, a_{3}\right]$ を算出するが，そ の解は(7)式に示寸相関係数行列 R の第一固有值 $\lambda_{1}$ に
$\mathrm{R}=\left[\begin{array}{ccc}1 & r_{x 1 x 2} & r_{x 1 x 3} \\ r_{x 2 x 1} & 1 & r_{x 2 x 3} \\ r_{x 3 x 1} & r_{x 3 x 2} & 1\end{array}\right]$

ここに，

$r=$ 相関係数

すなわち，下記の(8)式と(6)式に基づいて固有值入を 算出する。

$\left[\begin{array}{ccc}1 & r_{x 1 x 2} & r_{x 1 x 3} \\ r_{x 2 x 1} & 1 & r_{x 2 x 3} \\ r_{x 3 x 1} & r_{x 3 x 2} & 1\end{array}\right] \cdot\left[\begin{array}{l}a_{1} \\ a_{2} \\ a_{3}\end{array}\right]=\lambda \cdot\left[\begin{array}{l}a_{1} \\ a_{2} \\ a_{3}\end{array}\right]$

3 変数の主成分分析においては, 第二固有值 $\lambda_{2}$ を $\mathrm{R}$ の第二固有值に対応する固有ベクトルとして算出し, 同様にして第三固有值 $\lambda_{3}$ まで算出する。さらに, 三次 元点群デー夕に対して主成分分析を実施し, 算出した 固有值については, 構成する場所によって下記の性質 を持つとされている（伊達，2012）。

柱状点: $\lambda_{1} \gg \lambda_{2} \approx \lambda_{3}$

平面上点 : $\lambda_{1} \approx \lambda_{2} \gg \lambda_{3}$

その他の点: $\lambda_{1} \approx \lambda_{2} \approx \lambda_{3}$

ここに,

$\lambda_{1} \geq \lambda_{2} \geq \lambda_{3}$

固有值の傾向を示す状況については, 柱状点では図 8 (a)に示すように X 軸方向, Y 軸方向でのデータのば らつきに比べ， Z 軸方向でのデータのばらつきが大き い。すなわち，1軸方向のみでの変動が大きくなって いるために第一固有值である $\lambda_{1}$ のみが大きな值とし て算出される。一方, 平面上の点では先ほどの柱状点 とはことなり, X 軸方向, $\mathrm{Y}$ 軸方向でのデー夕のばら つきがほぼ同じになるのに対し，Z軸方向でのデー夕 のばらつきが極端に小さくなる。すなわち， 2 軸方向 での変動幅が大きくなるために第一固有值と第二固有 值である $\lambda_{1}, \lambda_{2}$ が同じような結果として算出されるの に対し, 第三固有值である $\lambda_{3}$ のみが小さな值として算 出される。さらに，その他の点では X 軸方向, $\mathrm{Y}$ 軸方 向, $Z$ 軸方向の各軸方向でのデータのばらつきが等し い状態であるため, 柱状点や平面上点とは異なり, 変 動幅が等しい状態となっているため，各固有值間での 


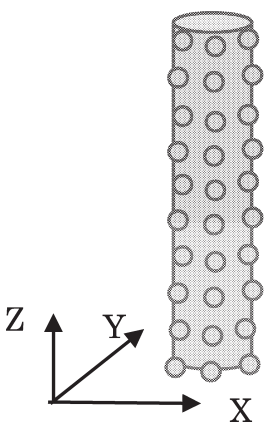

(a) 柱状点

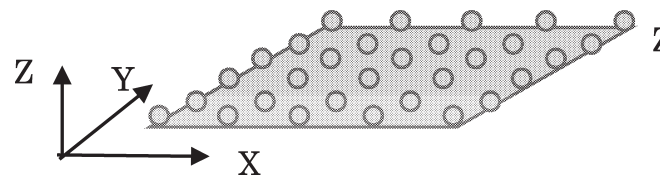

(b) 平面上点

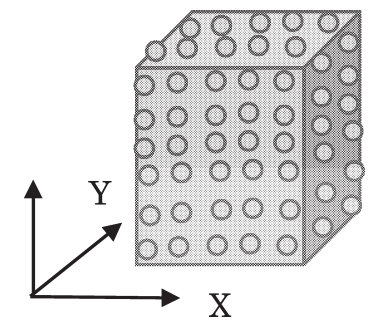

(c) その他の点

図 8 固有值傾向の状況図

結果は大きな違いがない結果が算出される。

本研究では, 計測データから地形や樹木の幹の部分, 樹木の枝葉 (樹冠) の部分など, 各部の固有值の比率 の違いを算出し，フィルタリングを行うことで計測結 果からの樹木の除去を検討した。なお，主成分分析を 用いて樹木の除去を行う場合，注目点を柱状点，平面 上点, その他の点のいずれに分類するかが問題となる。 閾值を手動で決定することも可能であるが，その根拠 を問われるために本研究では闇值を自動で設定する手 法を検討した。閾值の探索にあたり, 今回の主成分分 析においては $\lambda_{1}, \lambda_{2}, \lambda_{3}$ の三種類の閾值を設定する必要 があるが，樹木に相当する柱状点の分類を行う場合， $\lambda_{2}, \lambda_{3}$ については同じ值を閾值として設定するため, 実 質 “ $\lambda_{1} ” と “ \lambda_{2}, \lambda_{3}$ ” の 2 種類の閾值を自動で探索する こととした。

主成分分析を行う際には $\lambda_{1}, \lambda_{2}, \lambda_{3}$ の三種類の閾值を 変化させることで, 受光強度画像で確認されるデー夕 の点数が変化し, 徐々に閾值を変化させることでデー 夕点数の変化を追跡することが可能となる。今回は 2
種類の閾值を探索する必要があるが，同時に閾值を探 索することは難しい。よって, まず “ $\lambda_{2}, \lambda_{3}$ ”を固定し て“ $\lambda_{1}$ ”の変化が安定する閾值を探索し, その後, 探索 した “ $\lambda_{1} ”$ を固定して“ $\lambda_{2}, \lambda_{3}$ ”の変化が安定する閾值 を探索する。その後, “ $\lambda_{2}, \lambda_{3}$ ”と “ $\lambda_{1}$ ”の固定を繰り返 して両閾值に変化がなくなるまで探索を繰り返すこと とした。

閾值の自動探索手法を取り入れた主成分分析の結果 を図 9 に示す。

主成分分析で樹木を除去した場合, 一部の幹の部分 や樹木の根の部分については形状や地形部分の影響も あって柱状部分と認定されないために除去されていな いため, 地形情報の記録からは樹木の根のような部分 についても除去する必要がある。このような部分を除 去するにあたり, 本研究では注目点と隣接する点を距 離画像上で横方向に探索し, 点間の距離が所定の距離 内である点を連続した点群であると認定した後にその 点群の形状を把握することとした。

点間距離を算出するにあたり, 本研究ではレーザス

樹木のデータが

部分的に残留

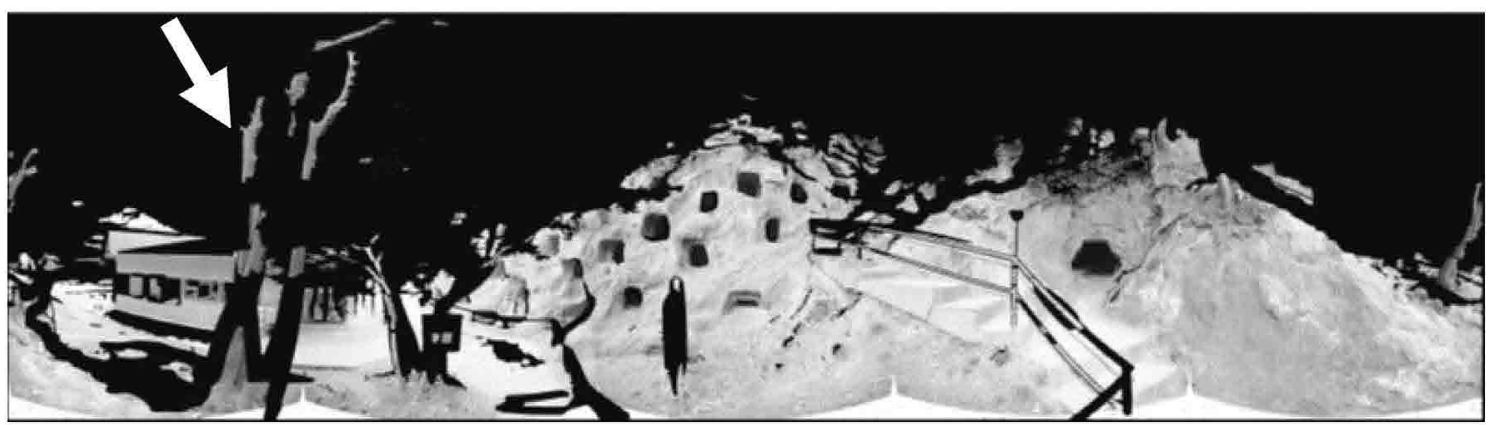

図 9 主成分分析による樹木除去結果 


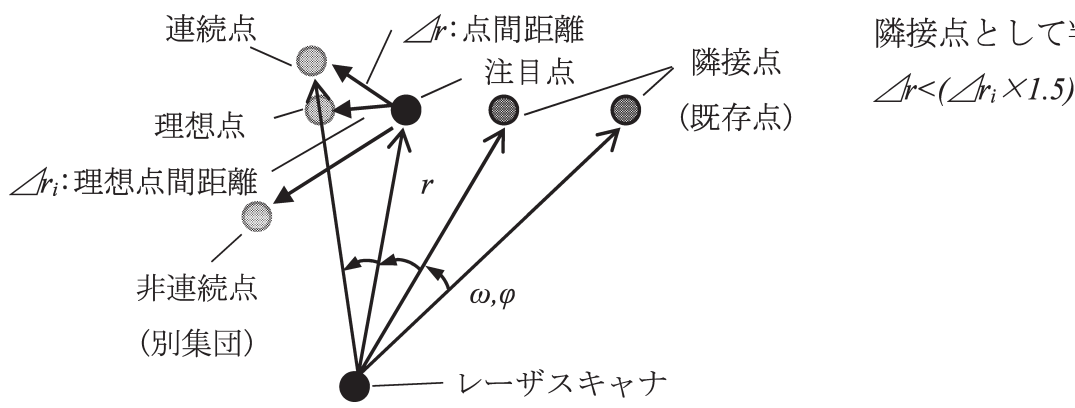

嶙接点として判断する条件

図10＼cjkstart隣接点の位置関係検討概念図

キャナ計測が水平・垂直方向ともにあらかじめ指定さ れた一定角度でレーザスキャナを中心とした放射方向 でレーザ光を照射していることに着目した。すなわち， 図10に示すように最初にレーザスキャナから注目点ま での距離を算出した後，あらかじめ算出してある垂 直・水平方向の振角から連続した場所を計測した場合 の隣接点までの理想的な距離を(9)式によって算出す る。次に計測データから算出した注目点と隣接する点 間の距離と理想点間距離を比較し，距離の差がほとん どない場合にはその隣接点は誤除去されたデー夕であ ると判断することとした。なお，推測した 2 点間距離 と実際の 2 点間距離の比較における判断の閾值は, 2 点間の位置関係が正対した状態から見て奥行き方向に 45度の傾きを持っている場所に存在する場所までを含 めるため, 推測した理想点間距離の 1.5 倍までの距離に ある点を連続した点群であると認めることとした。

$$
\begin{aligned}
& \Delta r_{z}=r \times \tan \varphi \\
& \Delta r_{x}=r \times \cos \varphi \times \cos \omega \\
& \Delta r_{y}=r \times \cos \varphi \times \sin \omega \\
& \Delta r=\left(\Delta r_{x}^{2}+\Delta r_{y}^{2}+\Delta r_{z}^{2}\right)^{1 / 2} \\
& \text { ここに, }
\end{aligned}
$$

$r:$ レーザスキャナから注目点までの斜距離 $\omega:$ 垂直方向振角, $\phi:$ 水平方向振角 $\Delta r_{x}, \Delta r_{y}, \Delta r_{z}: x, y, z$ 軸方向の点間距離

( $Z$ 軸を天頂方向と一致させた場合) $\Delta r$ : 注目点と隣接点（復活候補）までの理想距離 連続した点群であるとした点の集団（グループ）に ついては, 構成する各点の $x$ 座標データと $y$ 座標デー 夕と最小二乗法を用いて円の半径を算出し, 連続した 点群が一定半径以内であると判断される場合について はその集団は樹木の幹の部分を表す点群であると判断 し, 自動除去の対象とすることとした。なお, 本研究 では実在の樹木の実測データから根の部分の樹木の半 径 (閾值) を $0.2 \mathrm{~m}$ （直径：0.4m）として設定し，それ 以下の半径と推測される点群については計測結果から 除去した。その結果を図11に示す。

図 7 の結果に比べ，樹木の根元まで除去できている ことから，主成分分析と円形部の除去プロセスの組み 合わせによる樹木除去手法の有効性が確認される。し （9） かし，一部の地形が過剩に除去されているため，地形 を記録するという目的からすると, 削除した地形を何 らかの形で復元することが望ましい。

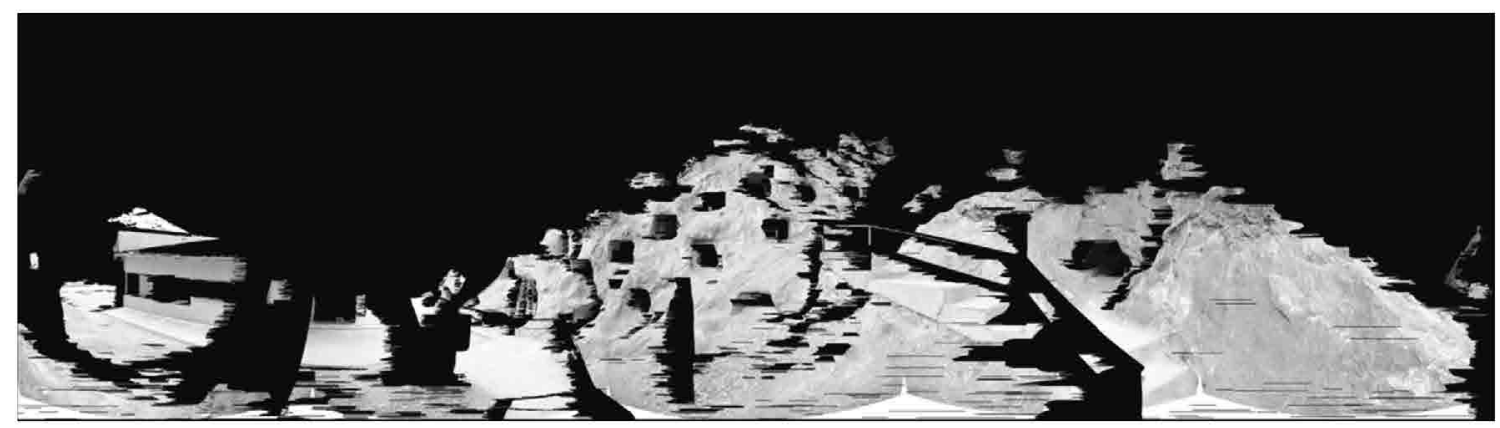

図11 主成分分析に加え円形部の除去プロセスを追加した結果 


\section{4. 誤除去後データの復活方法}

平坦性評価法を用いて取得した平坦度に対して，閾 值以上の点を樹木の葉部分などであるとして一律に計 測結果から除去した場合, 建屋の角 (エッジ) 部分や 奥行きの異なる斜面が重なっている部分の端部のよう な平坦度が大きくなりやすい部分も同時に誤って除去 される。一方，主成分分析と円形部の除去プロセスを 組み合わせた方法を用いた場合でも固有值傾向と設定 される闇值によって円形部であると判断された場所は 誤って削除される。この誤除去に関しては, 重み付平 均内挿法など周辺の計測結果から推測して補間デー夕 を作成することも考えられるが, 計測結果は存在して いるので, 誤除去前のオリジナルのデー夕を可能な限 り復活させることが望ましい。

本研究では過剩に除去された地形部分の復活を行う ため, 図10に示した理想とする隣接点の位置関係を類 推する方法を活用することとした。すなわち，距離画 像上で存在する点を探索し，隣接する点で削除された 点がないか探索，さらに存在する点と削除された点の 間の距離が一定值以下となる場合は過剩除去点である と判断し，復活することとした。なお，点の位置関係 を探索する際には, 画像距離上の注目点の左右方向と 下方向に探索方向を限定し，上方向には探索しないこ とで地表から生える樹木などを復活させないようにし た。また，点間距離の閾值については，自動除去を行 う際と同じく推測した理想点間距離の1.5倍以下の距 離にある隣接点を復活することとした。図11の結果に 対して隣接点間の位置関係を類推する手法を用いた䛊 除去デー夕の復活結果を図12に示す。

理想距離を用いて隣接点の位置関係を類推する本手
法の適用により，手すりのように手動での除去が必要 な部分が確認されるが，樹木の根元まで除去した状態 を維持しつつ，目視によって樹木と思われるほぼ全て の部分を自動で除去し，さらにまとまった形での地形 情報を記録できることが確認された。この結果に伴い， 理想点間距離を用いた誤除去データの復活方法に関す る有効性が確認された。

\section{5.まとめ}

本研究ではデジタルドキュメンテーションデータの 作成の合理化を目的に, 地上据置型レーザスキャナを 用いて樹木が含まれる遺構（地形）を計測した結果か ら，樹木などの地形以外のデー夕を自動で除去する方 法について検討を行った。

樹木の自動除去を行うにあたり，平坦性評価を用い た手法とエッジ特徵量を用いた方法の組み合わせや, 主成分分析を用いた方法を検討し，主成分分析を用い た方法に加え, 最小二乗法を用いた円形の認識による 樹木の自動除去を実現した。なお，主成分分析を用い た樹木の自動除去に関しては, 理想点間距離を用いて 誤除去した地形データの復活を行うことで，まとまっ た地形情報の記録が可能となることも併せて確認し た。このように, 地上据置型レーザスキャナを用いた 地形計測結果から樹木の自動除去を行うことにより, 文化財のデジタルドキュメンテーションへの活用が期 待されるだけでなく，多方面への応用も期待される。

具体的な応用先としては, 航空レーザからでは判別 が困難な詳細な地表面形状の記録や樹木を認識してい ることに着目し，樹木の樹幹や位置などを活用するこ とも考之られる。今後は, 除去精度の向上や効率化の 向上，樹木の除去を行った後の精度のよい地形の補間

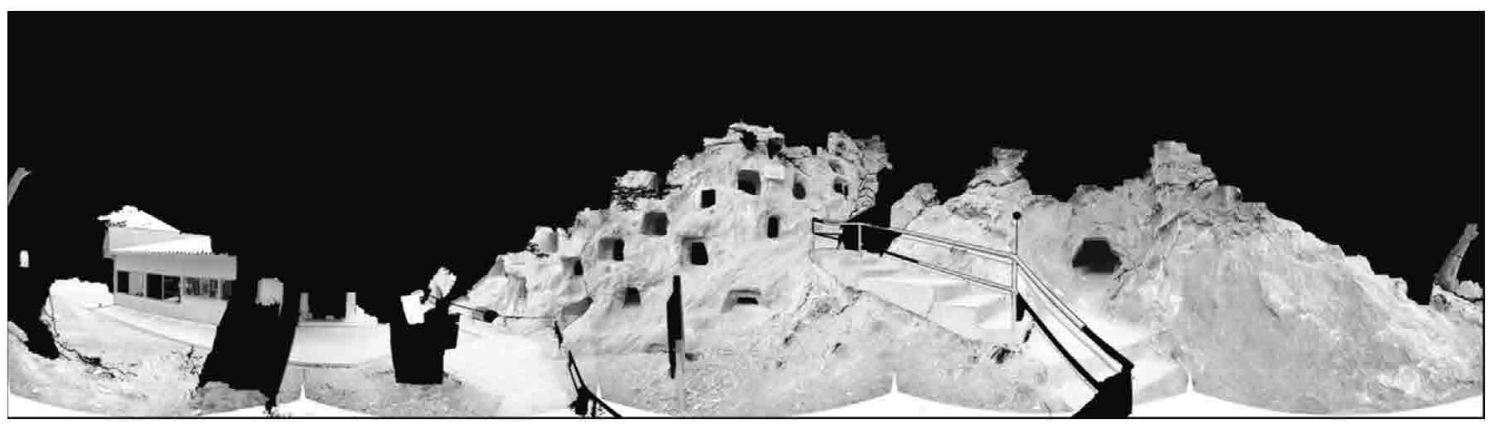

図12 誤除去データの復活結果 
方法の確立が課題と考えている。

\section{謝 辞}

本研究を進めるにあたり, リーグルジャパン株式会 社の松田重雄様, 佐及木公一様から地上据置型レーザ スキャナによる遺構の計測デー夕をご提供いただきま した。ここに改めて謝意を表します。

(受付日2015.5.8，受理日2015.9.18)

\section{参考文献}

1. 池内克史, 大石岳史, 2010. 3 次元デジタルアー カイブ，東京大学出版会

2 . 上田尚一，2003．主成分分析，朝倉書店

3 . 大野和則, 永谷圭司, 秋山英久, 2010. レスキュー ロボットの地図構築，日本ロボット学会誌，28(2), pp.169-172

4. 押尾晴樹, 浅輪貴史, 梅干野罧, 宮坂 聡, 2013. 航空機 LiDAR を用いた市街地における樹木の三次 元情報の整備手法 その 3 voxel モデリングによ る樹冠外形の再現, 日本建築学会大会学術講演梗概 集, pp.861-862とリモートセンシング, 43(3), pp.2229

5. 杉山岳弘, 阿部圭一, 1997. エッジベクトル抽出 器と複数エッジの解析, 電子情報通信学会論文誌, Vol. J80-D-II, No. 6 pp.1379-1389

6. 伊達宏昭, 2012. MMS 計測点群からの柱状物体抽 出, 動体計測研究会講演資料

7. 永田 靖, 棟近雅彦, 2001. 多変量解析法入門, サイエンス社

8. 西村正三，原 健司，木本啓介，松田 浩，2012. $3 \mathrm{D}$ レーザ・デジタル画像を用いた軍艦島計測と損 傷図作成, Journal of JSPRS, pp.46-53

9 . 山内裕之, 巽 耕一, 脇登志夫, 2008. 皇居東御 苑内本丸中之門石垣の修復工事と石垣修復支援シス テム, 建設の機械化/建設の施工企画, pp.47-52

10. 横山 大，2004。地上据置型レーザスキャナを用 いた地形計測のためのフィルタリング手法に関する 研究, 写真測量
11. Abdul Nurunnabi, David Belton and Geoff West, 2012. Robust Segmentation for Multiple Planar Surface Extraction in Laser Scanning 3D Point Cloud Data, 21st International Conference on Pattern Recognition (ICPR 2012), pp.1367-1370

12. Anita Schilling, Anja Schmidt, Hans-Gerd Maas, 2012. Principal Curves for Tree Topology Retrieval from TLS Data, Proceedings of SilviLaser 2012, ISPRS

13. Ee Hui Lim, David Suter, 2009. Ground filtering and vegetation mapping using multi-return terrestrial laser scanning, Computer-Aided Design, vol. 41, pp.701-710.

14. Francesco Pirotti, Alberto Guarnieri, Antonio Vettore, 2013. Ground filtering and vegetation mapping using multi-return terrestrial laser scanning, ISPRS Journal of Photogrammetry and Remote Sensing, vol. 76, pp.56-63

15. I. Satomos, M. Leordeanu, 2003. Automated Feature-based Range Registration of Urban Scenes of large scale., IEEE Internal Conference of Computer Vision and Pattern Recognition, Vo. 2, pp. 555-561.

16. N. Brodu, D. Lague, 2012. 3D terrestrial lidar data classification of complex natural scenes using a multi-scale dimensionality criterion: Applications in geomorphology, ISPRS Journal of Photogrammetry and Remote Sensing, vol. 68, pp. 121-134

17. Sooyoung Kim, Thomas Hinckley, David Briggs, 2011. Classifying individual tree genera using stepwise cluster analysis based on height and intensity metrics derived from airborne laser scanner data, Remote Sensing of Environment 115 (2011), pp.3329-3342

18. T. Sugiyama, K. Abe, 1995. Edge Height and reliability, Proc. ACCV '95, Singapole, Vol. II, pp. 410-414. 